\title{
The Reliability of Accruals and the Prediction of Future Cash Flow
}

\author{
Ehsan Khansalar \\ Lecturer in Accounting and Finance, Aberystwyth University \\ Old College, King Street, Aberystwyth \\ Ceredigion SY23 2AX, United Kingdom \\ E-mail: khansalarehsan@yahoo.com
}

Received: August 22, 2011

Accepted: September 13, 2011

Published: January 16, 2012

doi:10.5539/ijbm.v7n2p45

URL: http://dx.doi.org/10.5539/ijbm.v7n2p45

\begin{abstract}
The aim of this study is to investigate the reliability of accruals in predicting cash flows. Three categories of accrual are considered (trading, non-trading and financial accruals), which are calculated on the basis of the balance sheet information available in the Worldscope database. Different levels of reliability are assigned to the different types of accrual dependent on their expected propensity to manipulation, using a three-point scale of reliability (low, medium and high). We expect a higher degree of reliability in financial accruals to be associated with greater predictive power with respect to cash flows, and likewise for a lower level to be associated with lower predictability in non-trading accruals, and evidence is presented that supports these predictions.
\end{abstract}

Keywords: Accruals, Cash flows, Reliability, Cash flows predictability

\section{Introduction}

In this study, we investigate the relationship between the current accrual, the current cash flow and predictions of future cash flows.(Note 1) Prior research that addresses this issue includes the well-cited study by Dechow, Kothari, \& L. Watts (1998), which developed a modeling framework that has been widely used in the meantime in investigating the relation between earnings, accruals and cash flows. For their purposes, the only sources of accrual that were taken into account were changes in accounts receivable, accounts payable and inventory, based on the proposition that the predictability of future cash flows would be observable in working capital accruals, and leading to the conclusion that earnings better predict future operating cash flows than current operating cash flows.

The study that is described in this paper builds on this prior work, not only by extending the scope of accruals to include financial accruals and non-trading accruals, but also by examining the 'reliability' of the accrual estimates involved. In fact, a broader definition of accruals was employed by Barth, Cram, \& Nelson (2001) in a subsequent study of the association between accruals and future cash flows. They disaggregated accruals into the following components: changes in accounts receivable, accounts payable and inventory, plus depreciation, amortization and other accruals, positing that this sort of accrual categorization helps to improve the predictive power with respect to future cash flows, and moving the investigation away from the forward implications of aggregated accruals towards that of disaggregated accruals. Using this extended model, these authors show clearly how the various accrual components of earnings convey information not only about delayed cash flows arising from current trading arrangements but also give information with respect to future cash flows which are associated with management expectations about operating and investing activities in subsequent periods.(Note 2)

Noticeably, the reliability of the accruals disclosed in published financial statements was not taken into account at this stage, and one outcome of the studies cited above has been to raise questions as to why some accruals are associated with a high degree of predictability of future cash flows whilst others are not. For example, Barth, et al. (2001) show that long term accruals such as depreciation and amortization have significant predictive power with respect to future cash flow, although this is in contradiction to the results of MacDonald (1999) that suggest no such relationship. Richardson, Sloan, Soliman, \& Tuna (2005) have addressed this wider issue by focusing attention on the reliability of accrual estimates, arguing that the amount stated by way of an accrual is likely to be closer to a verifiable fair value for some identifiable categories of accruals rather than others. Financial accruals, therefore, could be associated with a higher level of predictability because of a higher level of reliability, attributable in the case of financial accruals to their greater proximity to observable market values, 
together with lower manipulation potential by comparison with, say, the inherent imprecision in provisions for risks, the ease with which timing changes can alter accounts receivable, and the way in which levels of discount and credit may be negotiated with suppliers.

The arguments in Richardson, et al. (2005) derive from the work of Sloan (1996), who first considered accrual reliability in the context of earnings persistence, whereby the accruals part of earnings can be shown to be associated with a lower degree of earning persistence than is the case for the cash flow part of earnings, this difference being attributable to the subjectivity of accruals. Richardson, et al. (2005) further developed this idea by disaggregating accruals on the basis of the balance sheet items that are involved, and in the following we can see how their accruals groupings are associated with reliability levels through a process of aggregation:

Changes in working capital accruals $(\triangle W C)$ : medium reliability - this outcome is based on averaging over two components with different assumed reliability levels, i.e. the change in current operating assets ( $\triangle C O A$ : short term receivables, inventory and other current assets), which is deemed to have low reliability, and the change in current operating liabilities ( $\triangle C O L$ : accounts payable, income taxes payable, other current liabilities) which are assigned high reliability.

Changes in non-current operating accruals $(\triangle N C O)$ : low/medium reliability - in this case, the outcome is again based on two components with different assumed reliability levels, i.e. the change in non-current operating assets ( $\triangle N C O A$ : property, plant and equipment, equity method investments, intangibles and other assets), which are considered as low reliability, and the change in non-current operating liabilities ( $\triangle N C O L$ : deferred taxes, minority interests and other liabilities) which are defined as medium reliability.

Changes in financial accruals $(\Delta F I N)$ : high reliability - this outcome is based on a preponderance of high reliability across three components, i.e. the change in short term investments $(\triangle S T I)$ with high reliability, the change in long term investments $(\triangle L T I)$ with medium reliability, and the change in financial liabilities $(\triangle F I N L$ : current debt, long term debt and preferred stock) with high reliability.(Note3)

The present study reconsiders this approach in estimating the associations between current accruals, current cash flows and expected future cash flows with regard to the role of reliability across accrual categories. In the above, the categories used are working capital accruals $(\triangle W C)$, non-current operating accruals $(\triangle N C O)$ and financial accruals $(\triangle F I N)$. However, although comprehensive, it is possible nevertheless that some balance sheet lines may not be embedded within these categories, such as provisions for risks and charges. The aim of this study is to ensure the inclusion of all such items in the categorization of accruals, so that the scope of accruals encompasses all nonequity accounts except cash. In so doing, we exclude from the accruals calculation only those balance sheet lines that relate to retained shareholders' equity, such as dividends payable, minority interests, non-equity reserves and preference share capital. This extended categorization of accruals, which is based on the balance sheet in its entirety, is operationalised in this paper using the Worldscope data source through Thomson One Banker.

As mentioned, the more comprehensive concept of accruals that underlies our approach greatly increases the definition beyond working capital. Hence, numerous earlier studies, from Healy (1985) to Watts \& Leftwich (1977), which focused on the operating accruals definition in FASB 95, omitted non-current accruals (such as capitalized expenditure on plant and equipment) and financial accruals. At the same time, the argument in favour of 'relevancy' (e.g. Lev \& Sougiannis, 1996) must be reconsidered too, given that less 'reliable' information that is albeit 'relevant' will have significantly adverse effects in any assessment of the quality of accounting numbers (Watts, 2003). This trade-off between reliability and relevancy is also a feature of the policy debate (see SFAC 2, paragraph 42), and our approach is to avoid this pre-selection based on relevance, and to assign reliability levels to all line items which is shown in table 1 .

Using Worldscope financial statement descriptors as the basis, as above, it is evident that the following balance sheet items have not been allocated to the accruals schedule: Common equity, Preferred stock, Dividends payable, Minority interests, Non-equity reserves and cash - as indicated earlier in the introduction. Clearly, the changes in these six remaining financial statement line items plus the accruals components tabulated above form one of the principal financial statement identities - the statement of changes in financial position - which sums to zero.

\section{Methodology}

In the study, three different groups of accruals with different levels of reliability have been compared with each other to see which group is more able to predict future cash flows than others.

Reliability levels in the balance sheet are measured as low, medium and high. It is to be expected that acruals with a high reliability level are associated with better performance in predicting future cash flows. For instance, 
short term investments or short term debt, which are marketable securities with a market value in the daily news of the stock exchange, are known as accruals with a high degree of reliability. They are expected to be more able than other accruals, such as depreciation which is known to have low level reliability, to predict future cash flows. Therefore non-trading accruals, like poperty, plant and equipment, are considered to have a low level of reliability because decisions regarding capitalization of expenses, choice of depreciation and amortization methods, or useful life and salvage values, depends on the manager's discretion and they are associated with the lowest level in predicting the future cash flows.

\subsection{The balance sheet items' reliability}

In this part we show how different level of accruals - low, medium and high - are attributed to the different parts of the balance sheet. We have assigned high level reliability only to those financial accruals which are short term, long term debt, or short term investments because their values are very close to the market value and it is observable that, for instance, buying and selling stock on the stock exchange is relatively straightforward or the value of a long term loan is evident. Low level reliability has been allocated to some of the traditional accruals items, like accounts receivable, inventory or property, plant and equipment. Other accruals are classified as those with a medium level of reliability.

\subsubsection{Trading accruals}

The first group, known as trading accruals, consist of trading activities such as inventories and accounts receivable and are equal to trading assets less trading liabilities.

$\Delta T$ represents the change in trading assets less the change in trading liabilities.

The definition of trading accruals is almost the same as the traditional definition of accruals that has been presented by Sloan (1996). In the work of Sloan accruals have been defined as the change in current operating assets, net of cash and short term investments, less the change in current operating liability, net of short-term debt. There are a few similarities and differences between the definitions of accruals based on the work of Sloan and this study. With regard to the similarities, cash, investment and debt have been taken out of assets and liabilities, but in terms of differences, both short term and long term assets and liabilities, like long term receivables and deferred incomes, have been included.

\section{Accounts Receivable}

The first item in the balance sheet and the first item in accruals are known as the trading accruals which is short term accounts receivable. Accounts receivable and inventory are known as accruals for centuries.

Accounts receivable and inventories are the components of current operating accruals (Thomas \& Zhang, 2002) and, as the only difference between trading assets and current operating assets, the long term receivables have been included in the current operating assets.

Accounts receivable are claims that are expected to be collected in cash so sometimes managers apply these items as a technique for manipulating the income, for instance by applying trade-loading and premature revenue recognition (Dechow, et al., 1998).

Long term receivables accruals are also associated with the lower degree of reliability because some firms apply these sorts of accounts to pay loans to related companies and subsidiaries.

\section{Inventory}

Inventories are an item in both balance sheet and income statement that are associated with large potential power in earnings management. The firm's earnings are managed whether by manipulating the inventory level, for instance by changing the number of inventory units or by applying different cost flow assumptions (FIFO, LIFO or weighted average) and subjective cost allocation for instance changing the method from FIFO to LIFO in the price increasing periods to decrease the earnings. If a company needs to increase its earnings when it has used the LIFO method (during price increase periods) it will need to keep old and cheap inventories in stock. When the entire units held in stock are sold and no new items are purchased, the desired earnings will be achieved. There are other methods of manipulating earnings which have made inventories one of the most unreliable items in the balance sheet; for example, recording inventories which do not exist', applying the lower-of-cost-or-market method or the principle of inventory writing-down by mistake. Inventories should be recorded based on the historical value but if the market value is lower than the historical value the entry should be based on the market value. As long as market values are not clear, there is room for managers to apply their own discretion and to manipulate earnings (Bauwhede \& Willekens, 2003). 
The next part of $\Delta \mathrm{TA}$ is pepaid expenses which are consistent with Sloan's definition and known as accruals. In this study we identified prepaid expenses as a component of $\Delta \mathrm{TA}$.

In the Financial Administration Act, 1993, section 15, prepaid expenses are defined as non-financial assets which result when payments are made in advance of the receipt of goods or services. Prepaid expenses may arise from payments for insurance premiums, leases, professional dues, memberships and subscriptions. Managers potentially tend to manipulate prepaid expenses by allocating a specific portion of prepaid expenses to the cost. For instance, if management wants to increase the EPS in a company, they need to allocate a small portion of prepaid expenses to expenses. Although it is assumed that there is a positive correlation between increasing a company's EPS and the magnitude of prepaid expenses, empirical works have still not confirmed this. Therefore this is not a clear way to judge the reliability level of these accruals. Hence we have assigned the medium level of reliability to them.

\section{Other current assets}

Based on Thomson One Banker, other current assets include: (i) deferred expenses that are not included in long term assets, (ii) property and assets held for disposal, (iii) deposits and advances to others, (iv) accrued $\mathrm{Ad}$ Valorem taxes, (v) deferred or future income tax benefits that are not shown as a long term asset, and (vi) industry-specific items such as program rights. We have assigned a low level of reliability to this part of the balance sheet because most of these items are associated with a high degree of earning manipulation. For instance, with regard to property and assets held for disposal, Shah, Butt, \& Hasan (2009) note the greater propensity of income-increasing firms to include non-cash revenues like asset disposal gains in earnings. Similarly, with regard to program rights, it may be noted that the Securities and Exchange Commission, in Accounting and Auditing Enforcement Release No. 2393, points to a case of a company that materially overstated its software assets by more than $400 \%$ by improperly capitalizing operating expenses.

In the end, trading asset because of existence of four items with the low level of reliability and also one item with the medium level of reliability is known as the accruals with the low level of reliability.

\subsubsection{Trading liabilities}

These accruals have been identified as those with medium level reliability. The decomposed trading liability accruals is begun with the first item of current liability which is the accounts payable.

\section{Accounts payable}

Laux (2007) notes accounts payable is one of the most reliable items in the balance sheet. In contrast with accounts receivable, account payable is associated with a high degree of reliability since by considering the going concern concept, firms have to pay their liability in full. So this particular part of the balance sheet cannot be manipulated to the same extent as accounts receivable. The only way to manipulate it is to estimate the magnitude of discount that might be offered by suppliers. Also, because the magnitude of accounts payable is based on suppliers' invoices which if not paid are followed up, the risk of manipulation of this item is lower than that for receivables. Assigning a low level of reliability to this part of accruals would be unfair, consequently it has been labeled medium level.

\section{Deferred income}

This is income received during an accounting period, but for which the company has not yet supplied the goods and services at the end of the period, so which cannot be recognised as income. These amounts should not be included in the income statement for the period.

The Wordscope database discloses these items separately, which is useful for financial modeling, because it makes future revenues more visible.

Deferred income includes:

(1) Fees received but not yet earned (e.g. advertising fees)

(2) Revenue normally included in income but deferred until earned and matched with expenses

(3) Prepaid income

To identify potential revenue manipulation, it is important to examine both accounts receivable and unearned revenue accruals. Most prior studies that focus on revenue manipulation and earnings management only examine accounts receivable accruals (e.g. Marquardt \& Wiedman, 2004). Unearned revenue and deferred income also play an important role in revenue manipulation. The low level of reliability has been allocated to this part of accruals. 
Laux (2007) notes that accrued payroll is considered to be one of the most reliable items in the balance sheet. Accrued payroll represents payroll expenses which are incurred within the normal operating cycle of the company but are not paid.

It includes:

(1) Commissions

(2) Vacation pay

(3) Profit sharing

(4) Incentive bonuses

(5) Pensions

Although the risk of manipulation in these items is lower than the risk for accounts receivable or inventories, still their values are not as clear as those of short term investment and short term debt whose market values are close to the fair value. Thus the high level of reliability would not be appropriate to these items and we have assigned normal level reliability to them in the balance sheet.

Income taxes payable

Men (2005) notes that the reliability of accounting information is influenced by the time differences which are reflected in income taxes payable. But still, as we mentioned earlier, they are not applied to manage earnings to the same extent as accounts receivable and inventories. So the low level of reliability cannot be attributed to this part of the balance sheet.

Other current liabilities:

Product guarantees, warranties and contingency reserves mean that the reliability of this part of the balance sheet is low level because they involve a high degree of expectation management and leave room for discretionary management exploitation.

Having considered all classes of trading liability accrual, its overall reliability level is determined as medium/low.

\subsubsection{Non-trading accruals}

The second group of accruals refers to non-trading activities because it includes all those items with a low turnover which are not considered for selling and buying, for example, property, plant and equipment. It is measured as the difference between change in non-trading assets $(\triangle \mathrm{NTA})$ and change in non-trading liabilities $(\triangle \mathrm{NTL})$. The low level of reliability has been assigned to this group of accruals.

$\Delta$ NTA includes:

Property, plant and equipment (PP\&E)

Intangibles

Investments in uconsol subsidiaries

Other investments

Other assets

Property, plant and equipment (PP\&E) and intangibles

Property, plant and equipment and intangibles are known as the traditionally unreliable items in the balance sheet which give some room for management to exploit their discretion (Holthausen, 1981).

This is because making a decision about capitalization of some of the expenses is unreliable, for example, making a decision to assign software development costs to the assets or to the expenses. Moreover depreciation and amortization method, useful life and salvage value are considered to be the most unreliable factors. Furthermore, PP\&E and intangibles have to write-down when they are determined to impair. The estimation of their impairment is highly unreliable.

\section{Investment in unconsolidated subsidiaries and other investments}

Based on the Wordscope database, investment in unconsolidated subsidiaries represents long term investments and advances in unconsolidated subsidiaries and affiliates in which the company has a business relationship or exercises control, and other investments represent all other investments of the insurance company besides fixed income and equity securities, real estate investments and mortgage and policy loans.

Management tries to maintain the incremental trend in the firm's profit because once the earnings disappointments (losses) appear, it causes large scale institutional investor selling and then a temporary undervaluation of the stock price of the firm. One of the ways to manage earnings is to seek out short term 
instead of long term investment to maintain the incremental trend for short term earnings; for example, by avoiding research and distribution costs which can lead to long term earnings. In other words, myopic investment behaviour is a sort of earnings management because it is a trade-off between reaching earnings targets and having a long term investment. Although low level reliability could be attributed to this part of the balance sheet, we have not done so in this study because they are not as unreliable as accounts receivable and inventories; here we recognise them as accruals with medium level reliability.

With regard to the other assets, the low level of reliability has been allocated to this part of the balance sheet as for the most part they are intangible assets which we have already assigned to the low level of reliability.

Overall, a low level of reliability has been allocated to the non-trading assets.

\subsubsection{Non-trading liabilities $\Delta$ NTL}

Non-Trading Liabilities include deferred taxes, Deferred tax liability in untaxed reserves, Provision for risks and charges and Other liabilities.

\section{Deferred taxes}

Deferred taxes represent the accumulation of taxes which are deferred as a result of timing differences between reporting sales and expenses for tax and financial reporting purposes. Holland \& Jackson (2004) have attributed the low level of reliability to the deferred taxes. In that study the level of the deferred tax was related to the following factors: whether the firm is reporting a pre-tax loss or a pre-tax profit; the extent of adjustment to prior year tax; and the level of surplus advance corporation tax (ACT). Hence we present these accruals with the low degree of reliability.

\section{Deferred tax liability in untaxed reserves}

Deferred tax liability in untaxed reserves represents the portion of untaxed reserves that is allocated to deferred taxation hence, as with deferred tax, the low level of reliability is assigned to this part of the balance sheet. The database it is only applicable to Finnish, Norwegian and Swedish consolidated results for comparison purposes with other countries. This study was not constructed based on these countries.

\section{Provision for risks and charges}

Provision for risks and charges found in non-U.S. corporations includes provisions for pension funds, repairs and maintenance, litigation claims, etc. To manage earnings, management take large restructuring charges or increase provisions for bad debts or take other income decreasing accounting decisions. Given the self-adjusting nature of accounting, these will lead to boosts in future income in the form of expenses that will not need to be recognized. The low level of reliability has been assigned to this item.

Although the medium level of reliability has been assigned to the other liabilities, still non-trading liability accruals are considered to be accruals with low level reliability. Ultimately, the low level of reliability is attributed to non-trading accruals.

\subsubsection{Financial accruals}

The last group of accruals refers to financial activities so is named the change in net financial activities ( $\Delta \mathrm{FIN})$. It has been calculated as the change in short-term investments less the change in short-term debt and long-term debt. These sorts of accruals have been ignored in prior research. $\Delta$ FIN comprises the change in short term investment $(\triangle \mathrm{SINV})$ and financial liability $(\triangle \mathrm{FINL})$. These are the most reliable accruals because the short investment value is so close to its fair value; indeed in some cases it is considered to be a cash equivalent. Stockholders, for example, are able to buy or sell their shares instantly which means the value of these balance sheet items is extremely close to the market value. Short term debt and long term debt are shown in the present value of future cash flows that will pay by the firm with the fixed interest rate at the time of issue and also their values are so close to the market value. Hence both short term investment and financial liability are associated with the high degree of reliability.

\section{Data}

Our sample is based on the Wordscope database which is available through the Thomson One Banker online resource. We chose 2,120 firms between 1991 and 2008 in the UK. 38,160 firms-years have been presented in this study.

At first we deflated all variables based on the average of total assets but we found that some firms' accruals are larger than the average of total assets which is unreasonable and was the cause of statistical problems. For these reasons, we deflated all the variables based on total assets of the same year for every single firm. 


\section{Results}

In this part of the study we present the results of the empirical work and also a comparison between our findings and those of Richardson. We start with the descriptive statistics.

\subsection{Descriptive statistics}

In this section, mean and standard deviation of deflated total accruals and its components which are trading accruals, non-trading accruals and financial accruals have been computed.

As can be seen in Figure 1, the mean for the total accruals is 0.26 which is about five times larger than the mean in the work of Richardson which was 0.052 . This might have happened because Richardson's statistics were drawn from the UK market.

Before going through the details of the descriptive statistics it is necessary to explain the importance of the accruals sign. In fact in calculating accruals based on the balance sheet method two accruals with the same value but with different signs have the same power but in different directions. The overall accruals sign in this study is positive which is the reason for using more non-cash assets in comparison with non-cash liabilities. It is also reasonable because the equity part of the balance sheet has not been considered in these accruals. In some prior studies the mean of total accruals is negative, for instance, the work of Sloan (1996) was not based on calculating accruals on the balance sheet method, because depreciation and amortization have been included in the accruals. With regard to the signs of means, deflated trading accruals and deflated non-trading accruals have positive means, and deflated financial accruals, in line with prior research, are associated with negative means. The negative mean indicates that the average firm is growing its net trading assets and reducing its financial assets, for instance increasing debt to finance this growth.

All the decomposed accruals are presented with a positive sign, except for financial accruals. This is because the assets (short term investments) are smaller than the liabilities (long and short term debt).

As mentioned earlier, trading accruals are very close to traditional working capital accruals and, as can be seen, trading accruals account for the smallest proportion of total accruals. Previous studies have ignored other accruals which in this study are referred to as non-trading and financial accruals.

Moreover, adding together these three accruals gives us the total accruals mean. The largest magnitude among the decomposed accruals' factors has been attributed to non-trading accruals and this is because of the large magnitude of PP\&E which resulted in a large accrual with a positive sign. Also, as previously mentioned, the negative sign of financial accruals is because of the small amount of short term investment which, for some of the firms, is close to zero, compared with the large magnitude of short and long term debt. Hence because of the large difference between these two items and also because short term investment is close to zero, there is a large standard deviation for financial accruals although it could also be expected that the firms' debt positions are unstable. Moreover, it is not be possible to use standard deviation as the index for recognising reliability level; if it were, then we would have to call PP\&E the most reliable item because of its low turnover which is sometimes close to zero.

The study finds that the most unreliable item, which is non-trading accruals, is associated with the highest mean which shows that management try to apply these sorts of accruals more than other decomposed accruals because they provide latitude for manipulating a firm's reality. For instance, applying different approaches to depreciation, or applying different bases for calculating depreciation, or allocating different amounts to the provision for risks and charges will have an effect on the firm's situation. The second largest accrual figure is for financial accruals. Although this is about -0.21 , it is still larger than that of trading accruals with a value of 0.08 , because as mentioned earlier we have to ignore the sign and consider it as 0.21 which is the result of a large amount of financial liability.

Therefore the incentive to use these accruals is less than that to use non-trading accruals as its mean is lower, because there is less room for management to apply their discretion.

\subsection{Accrual correlations (Pearson and Spearman Test)}

In table 2 we present the Pearson and Spearman correlations for the initial (major) accrual decompositions. The Pearson correlations have been presented above the diagonal and the Spearman correlations have been presented below it. As can be seen for all variables the coefficients are significance and also the largest coefficients in the table have been assigned to the link between financial accruals and total accruals which are 0.56 and 0.51 for Pearson and Spearman, respectively and both are significant. This shows that financial accrual among others is correlated more strongly to total accruals. Moreover the negative sign of the non-trading accruals could be interpreted as showing that the increase in the net non-financial assets could be a result of using the financial 
assets and operating assets or of increasing the financial liabilities (debt) and operating liability. The most important point in this table, however, is the strong relationship between this item and the total accruals.

Figure 2 presents descriptive statistics for accrual decompositions. Some relationships between assets and liabilities in this table have been presented like the relation between standard deviation of $\triangle \mathrm{TA}$ and $\triangle \mathrm{TL}$ and the relation between the standard deviation $\triangle$ FINA and $\triangle$ FINL.

Before going further, an explanation is required with respect to the accruals sign. In calculating each type of accrual we need to subtract liabilities of assets so the positive correlation between liabilities and assets shows the off-setting effects on total accruals. In table $3, \Delta \mathrm{TA}$ and $\triangle \mathrm{NTA}$ are positively correlated with $\triangle \mathrm{TL}$ and $\Delta \mathrm{NTL}$; for example, the Pearson and Spearman correlations between trading assets and trading liability are 0.38 and 0.51 respectively which are highly correlated and also the Pearson correlation between non-trading assets and non-trading liabilities indicate a coefficient with a positive value of 0.12 . These correlations indicate the trading and non-trading liabilities as one of the resources to finance the growth in the trading and non-trading assets.

As can be seen in Figure 2, the means of decomposed accruals have also been presented. Compared to Figure 1, the means are closer to the study's expectations as the research expected management to use fewer reliable than unreliable items, such as short term receivables as they would not exploit their discretion in order to manipulate the firms' truth. Thus the decomposed financial accruals (short term investment and short term and long term debt) are associated with the lowest means (except with regard to the non trading accruals) which indicates that management avoid applying this sort of accrual because they give little room for misrepresenting a firm's true situation. Moreover, we can expect that short term investments are considered to be the most reliable items as their magnitude is about 0.02 which is smaller by about 4 times than the second item which is non-trading liabilities. This shows that it would not be an attractive item for management to use as an accrual.

\subsection{Cash flow predictability}

First, Table 4 indicates the relationship between aggregated accruals and cash flows with regard to future cash flows (the average of a year ahead cash flow) which shows as:

$$
\mathrm{CASH}_{i, t+1}=\alpha+\beta_{1} \mathrm{CASH}_{i, t}+\beta_{2} \mathrm{TACC}_{i, t}+\varepsilon
$$

As can be seen, the coefficient of current cash flow in predicting future cash flow is about 0.07 larger than the coefficient of total accruals, at 0.26 and -0.19 , respectively. In Table 5, the accruals have been decomposed to investigate the predictive power of every single item with regard to future cash flow. The regression in Table 5 is presented below:

$$
\mathrm{CASH}_{i, t+1}=\alpha+\boldsymbol{\beta}_{1} \mathrm{CASH}_{i, t}+\boldsymbol{\beta}_{2} \Delta \boldsymbol{T}_{i, t}+\boldsymbol{\beta}_{3} \Delta N \boldsymbol{T}_{i, t}+\boldsymbol{\beta}_{4} \Delta F I N_{i, t}+\varepsilon
$$

A combination of "univariate" and "multivariate" regression analyses are shown in Table 5. Based on the univariate regressions the predictive power of each component of accruals is investigated separately. The findings, as we expected, indicate that $\Delta$ FIN has a high degree of reliability and is associated with a higher degree of cash flow predictability (-0.9 with a t-value of -10.09) Moreover, in the multivariate regression we found the same result because the coefficient for ... was about -0.23 and the t-value -5.43 . Hence again financial accruals are identified as a powerful indicator in predicting future cash flow. Also, the other two components of accruals, which are trading accruals and non-trading accruals, are identified as the second and third best predictors in predicting future cash flows.

In Table 6, the more extended decomposition of accruals has been presented as below:

$$
\mathrm{CASH}_{i, t+1}=\alpha+\beta_{1} \mathrm{CASH}_{i, t}+\beta_{2} \Delta \mathrm{TA}_{i, t}+\beta_{3} \Delta \mathrm{TL}_{i, t}+\beta_{4} \Delta N T A_{i, t}+\beta_{5} \Delta N T L_{i, t}+\beta_{6} \Delta F I N A_{i, t}++\beta_{7} \Delta F I N L_{i, t}+\varepsilon
$$

The regression results support our expectations that the reliability level of $\triangle \mathrm{TA}$ and $\triangle$ NTA would be lower than those of $\Delta \mathrm{TL}$ and $\Delta \mathrm{NTL}$. Therefore both $\Delta \mathrm{TL}$ and $\triangle \mathrm{NTL}$ are associated with the higher degree of cash flow prediction. With regard to the financial accruals, financial assets and financial liabilities produced the largest coefficients in predicting future cash flow. The most important point is that when comparing assets and liabilities, liabilities, which this study recognises as the more reliable items, are always associated with a higher degree of cash flow prediction. Moreover, financial accruals are the best predictors in the balance sheet for predicting future cash flow performance. Also, the problem raised in the last table with regard to comparing the predictive power of non-trading liability and financial liabilities has been solved as the predictive power of financial liability is greater than that of non-trading liabilities.

\section{Conclusion}

We have investigated the relationships between current and future cash flows and accruals and have presented some important notes. We provide a complete definition and categorization of accruals that incorporates many 
accruals that have been ignored by previous research. Our results show that some of the accrual categories that have been ignored by previous research have particularly low reliability. Also we find that financial accruals among other accruals have the high significant coefficients in predicting future cash flows in compare of other components of accruals which are trading and non-trading accruals. Incidentally, our study is a crucial trade-off between relevance and reliability in accrual accounting. We show that less reliable accruals introduce costs in the form of lower cash flow prediction.

\section{References}

Barth, M. E., Cram, D. P., \& Nelson, K. K. (2001). Accruals and the prediction of future cash flows. Accounting Review, 76(1), 27-58.

Bauwhede, H. V., \& Willekens, M. (2003). Earnings management in Belgium: a review of the empirical evidence. Tijdschrift voor economie en management, 43(2), 199-218.

Dechow, P. M., Kothari, S. P., \& L. Watts, R. (1998). The relation between earnings and cash flows. Journal of Accounting and Economics, 25(2), 133-168. http://dx.doi.org/10.1016/S0165-4101(98)00020-2

Healy, P. M. (1985). The effect of bonus schemes on accounting decisions. Journal of Accounting and Economics, 7(1-3), 85-107. http://dx.doi.org/10.1016/0165-4101(85)90029-1

Holland, K., \& Jackson, R. H. G. (2004). Earnings management and deferred tax. Accounting \& Business Research, 34(2), 101-123.

Holthausen, R. W. (1981). Evidence on the effect of bond covenants and management compensation contracts on the choice of accounting techniques: the case of the depreciation switch-back. Journal of Accounting and Economics, 3(1), 73-109.

Laux, J. A. (2007). Accounting issues: an essay series part I-introduction to accounting thery and 'cash. Journal of College Teaching \& Learning, 4 (1), 61-65

Lev, B., \& Sougiannis, T. (1996). The capitalization, amortization, and value-relevance of R\&D. Journal of Accounting and Economics, 21(1), 107-138. http://dx.doi.org/10.1016/0165-4101(95)00410-6

MacDonald, E. (1999). First call will add cash EPS estimates for 20 web firms, responding to street. Wall Street Journal 1.

Marquardt, C. A., \& Wiedman, C. I. (2004). How are earnings managed? an examination of specific accruals. Contemporary Accounting Research, 21(2), 461-491. http://dx.doi.org/10.1506/G4YR-43K8-LGG2-F0XK

Men, R. (2005). Optimal accounting method of income taxes for chinese enterprises under new environment. China-USA Business Review, 4(3), 17-21.

Richardson, S. A., Sloan, R. G., Soliman, M. T., \& Tuna, I. (2005). Accrual reliability, earnings persistence and stock prices. Journal of Accounting and Economics, 39(3), 437-485. http://dx.doi.org/10.1016/j.jacceco.2005.04.005

Shah, Z. A., Butt, S. A., \& Hasan, A. (2009). Corporate governance and earnings management an empirical evidence form pakistani listed companies. European Journal of Scientific Research, 26(4), 624-638.

Sloan, R. G. (1996). Do stock prices fully reflect information in accruals and cash flows about future earnings? Accounting Review, 71(3), 289-315.

Thomas, K. J., \& Zhang, H. (2002). Inventory changes and future returns. Review of Accounting Studies, 7(2), 163-187.

Watts, R. L. (2003). Conservatism in accounting part I: explanations and implications. Accounting Horizons, 17(3), 207-221.

Watts, R. L., \& Leftwich, R. W. (1977). The time series of annual accounting earnings. Journal of Accounting Research, 15(2), 253-271. http://dx.doi.org/10.2307/2490352

\section{Notes}

Note 1. This research issue is central to the ongoing policy debate. For instance, in International Accounting Standard IAS I, which was revised in September 2007, one of the objectives of accounting that is made more explicit is that of helping financial statement users in predicting the entity's future cash flows. In FASB pronouncements, a strong position is taken in this respect, in that accrual earnings are claimed to be better predictors of future cash flows than past cash flows alone (SFAC 5, par. 24). This has become a controversial issue, in the light of empirical financial accounting research, with findings such as those of Bowen et al. (1986) inferring that cash flow is a better predictor than earnings of one and two years ahead cash flow, which can be 
seen to counter the FASB view that earnings make better forecasts of future cash flows than cash flow itself.

Note 2. This issue is explored further in Dargenidou, McLeay and Raonic (2010).

Note 3. Note that preferred stock and minority interests are treated as financial accruals and non-current operating accruals respectively, whereas we assign these to equity together with two other items in the balance sheet which are not mentioned in the Richardson work, dividends payable and non-equity reserves.

Table 1.

\begin{tabular}{|c|c|c|c|c|c|}
\hline Accrual Line Items & & & Reliabi & y Level & \multirow{13}{*}{ Medium/Low } \\
\hline$\Delta$ Trading assets (TA) & & \multirow{6}{*}{$\Delta T A$} & \multirow{6}{*}{ Low } & \multirow{12}{*}{$\begin{array}{c}\text { Trading accrual } \\
(\Delta \mathrm{T})\end{array}$} & \\
\hline Short term receivables & Low & & & & \\
\hline Long term receivables & Low & & & & \\
\hline Inventory & Low & & & & \\
\hline Prepaid expenses & Medium & & & & \\
\hline Other current assets & Low & & & & \\
\hline$\Delta$ Trading liabilities (TL) & & \multirow{6}{*}{$\Delta \mathrm{TL}$} & \multirow{6}{*}{ Medium/Low } & & \\
\hline Accounts payable & Medium & & & & \\
\hline Deferred income & Low & & & & \\
\hline Accrued payroll & Medium & & & & \\
\hline Income taxes payable & Medium & & & & \\
\hline Other current liability & Low & & & & \\
\hline$\Delta$ Non-trading assets (NTA) & & \multirow{6}{*}{$\triangle \mathrm{NTA}$} & \multirow{6}{*}{ Low } & \multirow{11}{*}{$\begin{array}{c}\text { Non-trading accruals } \\
\qquad(\Delta \mathrm{NT})\end{array}$} & \multirow{11}{*}{ Low } \\
\hline Property, plant and equipment & Low & & & & \\
\hline Intangible assets & Low & & & & \\
\hline Investment in unconsolidated subsidiaries & medium & & & & \\
\hline Other investment & medium & & & & \\
\hline Other assets & Low & & & & \\
\hline$\Delta$ Non-trading liability (NTL) & & \multirow{5}{*}{$\Delta \mathrm{NTL}$} & \multirow{5}{*}{ Low } & & \\
\hline Deferred taxes & Low & & & & \\
\hline Deferred tax liability in untaxed reserves & Low & & & & \\
\hline Provision for risks and charges & Low & & & & \\
\hline Other liabilities & medium & & & & \\
\hline$\Delta$ Financial assets (FINA) & & & \multirow{2}{*}{ High } & \multirow{5}{*}{$\begin{array}{c}\text { Financial accrual } \\
\qquad(\Delta \mathrm{FIN})\end{array}$} & \multirow{5}{*}{ High } \\
\hline Short term investments & High & $\triangle$ FINA & & & \\
\hline$\Delta$ Financial liabilities (FINL) & & \multirow{3}{*}{$\Delta \mathrm{FINL}$} & \multirow{3}{*}{ High } & & \\
\hline Short term debt & High & & & & \\
\hline Long term debt & High & & & & \\
\hline
\end{tabular}

Table 2 .

\begin{tabular}{|c|c|c|c|c|}
\hline \multicolumn{5}{|c|}{$\begin{array}{c}\text { Correlation matrix Above the diagonal is Pearson } \\
\text { Correlation Test and below that is Spearman Test }\end{array}$} \\
\hline & TACC & $\Delta \mathbf{T}$ & $\Delta \mathbf{N T}$ & $\Delta$ FIN \\
\hline \multirow{2}{*}{ TACC } & & $\begin{array}{c}0.48 \\
(0.0001)\end{array}$ & $\begin{array}{c}0.29 \\
(0.0001)\end{array}$ & $\begin{array}{c}0.56 \\
(0.0001)\end{array}$ \\
\hline \multirow{2}{*}{$\Delta \mathbf{T}$} & $\begin{array}{c}0.34 \\
(0.0001)\end{array}$ & & $\begin{array}{c}-0.42 \\
(0.0001)\end{array}$ & $\begin{array}{c}0.38 \\
(0.0001)\end{array}$ \\
\hline \multirow{2}{*}{$\Delta \mathbf{N T}$} & $\begin{array}{c}0.23 \\
(0.0001)\end{array}$ & $\begin{array}{c}-0.55 \\
(0.0001)\end{array}$ & & 0.18 \\
\hline \multirow{2}{*}{$\Delta$ FIN } & $\begin{array}{c}0.51 \\
(0.0001)\end{array}$ & $\begin{array}{c}\mathbf{0 . 0 1 7} \\
(0.54)\end{array}$ & $\begin{array}{c}0.32 \\
(0.0001)\end{array}$ & \\
\hline
\end{tabular}

TACC is total accruals based on the balance sheet approach and it equals changes in total trading accruals $(\Delta \mathrm{T})$ changes in total non-trading accruals $(\Delta \mathrm{NT})$ - changes in total financial accruals $(\Delta \mathrm{FIN})$. Then all of these accruals have been deflated with the average total assets.

We show items that are not significant in Bold. 
Table 3.

\begin{tabular}{l} 
Correlation matrix Above the diagonal is Pearson Correlation Test and below that is \\
Spearman Test \\
\hline
\end{tabular}

TACC is total accruals based on the balance sheet approach and it equals changes in total trading accruals $(\Delta \mathrm{T})-$ changes in total non-trading accruals $(\Delta \mathrm{NT})$ - changes in total financial accruals $(\Delta \mathrm{FIN})$. Then all of these accruals have been deflated with the average total assets.

$\Delta \mathrm{T}$ or changes in trading accruals $=$ changes in trading asset accruals $(\Delta \mathrm{TA})-$ changes in trading liability accruals $(\Delta \mathrm{TL})$

$\Delta \mathrm{TA}$ or changes in trading asset accruals $=$ Receivables + Long term receivables (trading part) + Inventory + Prepaid expenses + Other current assets

$\Delta \mathrm{TL}$ or changes in trading liability accruals $=$ Deferred Income + Account payable + Accrued Payroll + Income taxes payable+ Other current liability

$\Delta$ NTA or changes in non-trading assets $=$ Property, plant and equipment, net + Investments in Unconsol Subsidiaries + Other Investments + Intangibles + Other assets

$\Delta$ NTL or changes in non-trading assets $=$ Deferred taxes + Deferred Tax Liability in Untaxed Reserves + Provision for Risks and Charges+ Other liability

$\triangle$ FINA or changes in financial assets $=$ Short term investments

$\triangle \mathrm{FINL}$ or changes in financial liabilities $=$ Short term debt + Long term debt.

Table 4.

\begin{tabular}{|l|c|c|c|}
\hline \multicolumn{4}{|c|}{ OLS regrssions for total accruals } \\
\hline \multicolumn{3}{|c|}{$\boldsymbol{C A S H}_{i, t+1}=\alpha+\beta_{1} \boldsymbol{C A S H}_{i, t}+\boldsymbol{\beta}_{2} \boldsymbol{T A C C} \boldsymbol{C}_{i, t}+\boldsymbol{\varepsilon}$} \\
\hline \multirow{2}{*}{$\begin{array}{l}\text { Mean coefficient } \\
\text { T statistics }\end{array}$} & Intercept & Cash & TACC \\
\cline { 2 - 4 } & 0.05 & 0.26 & $\begin{array}{c}-0.19 \\
(-4.64)\end{array}$ \\
\hline
\end{tabular}


Table 5.

\begin{tabular}{|c|c|c|c|c|c|}
\hline \multicolumn{6}{|c|}{ OLS regression for the initial accrual decomposition } \\
\hline \multicolumn{6}{|c|}{$\mathrm{CASH}_{i, t+1}=\alpha+\beta_{1} \mathrm{CASH}_{i, t}+\beta_{2} \Delta T_{i, t}+\beta_{3} \Delta N T_{i, t}+\beta_{4} \Delta F I N_{i, t}+\varepsilon$} \\
\hline \multirow{2}{*}{ Predicted reliability } & \multirow{2}{*}{ Intercept } & \multirow{2}{*}{ Cash } & $\Delta \mathrm{T}$ & $\Delta \mathrm{NT}$ & $\Delta \mathrm{FIN}$ \\
\hline & & & Medium & Low & High \\
\hline Mean coefficient T statistics & 0.12 & 0.26 & $\begin{array}{c}-0.04 \\
(-1.27)\end{array}$ & & \\
\hline Mean coefficient T statistics & 0.21 & 0.14 & & $\begin{array}{c}-0.07 \\
(-4.79)\end{array}$ & \\
\hline Mean coefficient T statistics & -6.5 & 0.06 & & & $\begin{array}{l}-0.09 \\
(-10.9)\end{array}$ \\
\hline Mean coefficient $\mathrm{T}$ statistics & -0.007 & 0.36 & $\begin{array}{c}-0.04 \\
(-0.85)\end{array}$ & $\begin{array}{c}-0.03 \\
(-0.69)\end{array}$ & $\begin{array}{c}-0.23 \\
(-5.43)\end{array}$ \\
\hline
\end{tabular}

Table 6.

\begin{tabular}{|c|c|c|c|c|c|c|c|c|}
\hline \multicolumn{9}{|c|}{ OLS regressions for decomposed accruals } \\
\hline \multicolumn{9}{|c|}{$C A S H_{i, t+1}=\alpha+\beta_{1} C A S H_{i, t}+\beta_{2} \Delta T A_{i, t}+\beta_{3} \Delta T L_{i, t}+\beta_{4} \Delta N T A_{i, t}+\beta_{5} \Delta N T L_{i, t}+\beta_{6} \Delta F I N A_{i, t}++\beta_{7} \Delta F I N L_{i, t}+\varepsilon$} \\
\hline \multirow{2}{*}{ Predicted reliability } & \multirow{2}{*}{ Intercept } & \multirow{2}{*}{ Cash } & $\Delta \mathrm{TA}$ & $\Delta \mathrm{TL}$ & $\Delta$ NTA & $\Delta \mathrm{NTL}$ & $\Delta$ FINA & $\Delta \mathrm{FINL}$ \\
\hline & & & Low & High & Low & Medium & High & High \\
\hline $\begin{array}{l}\text { Mean coefficient T } \\
\text { statistics }\end{array}$ & -3.56 & 0.03 & $\begin{array}{c}0.08 \\
(3.41)\end{array}$ & & & & & \\
\hline $\begin{array}{l}\text { Mean coefficient T } \\
\text { statistics }\end{array}$ & -0.27 & 0.16 & & $\begin{array}{l}0.11 \\
(8.1)\end{array}$ & & & & \\
\hline $\begin{array}{l}\text { Mean coefficient T } \\
\text { statistics }\end{array}$ & 1.2 & 0.03 & & & $\begin{array}{c}0.009 \\
(-0.86)\end{array}$ & & & \\
\hline $\begin{array}{l}\text { Mean coefficient } \mathrm{T} \\
\text { statistics }\end{array}$ & -0.18 & 0.16 & & & & $\begin{array}{l}0.22 \\
(18)\end{array}$ & & \\
\hline $\begin{array}{l}\text { Mean coefficient T } \\
\text { statistics }\end{array}$ & -4.84 & 0.08 & & & & & $\begin{array}{c}-0.04 \\
(-4.01)\end{array}$ & \\
\hline $\begin{array}{l}\text { Mean coefficient } \mathrm{T} \\
\text { statistics }\end{array}$ & -16.7 & 0.05 & & & & & & $\begin{array}{c}0.03 \\
(3.05)\end{array}$ \\
\hline $\begin{array}{l}\text { Mean coefficient T } \\
\text { statistics }\end{array}$ & 0.06 & 0.38 & $\begin{array}{l}-0.03 \\
(-0.11)\end{array}$ & $\begin{array}{c}0.1 \\
(2)\end{array}$ & $\begin{array}{c}0.001 \\
(0.005)\end{array}$ & $\begin{array}{l}-0.09 \\
(-2.16)\end{array}$ & $\begin{array}{l}-0.11 \\
(-2.5)\end{array}$ & $\begin{array}{l}0.23 \\
(5.3)\end{array}$ \\
\hline
\end{tabular}


Descriptive statistics for initial accruals. The smple consist of 38,160 firm-years between 1991 and 2008

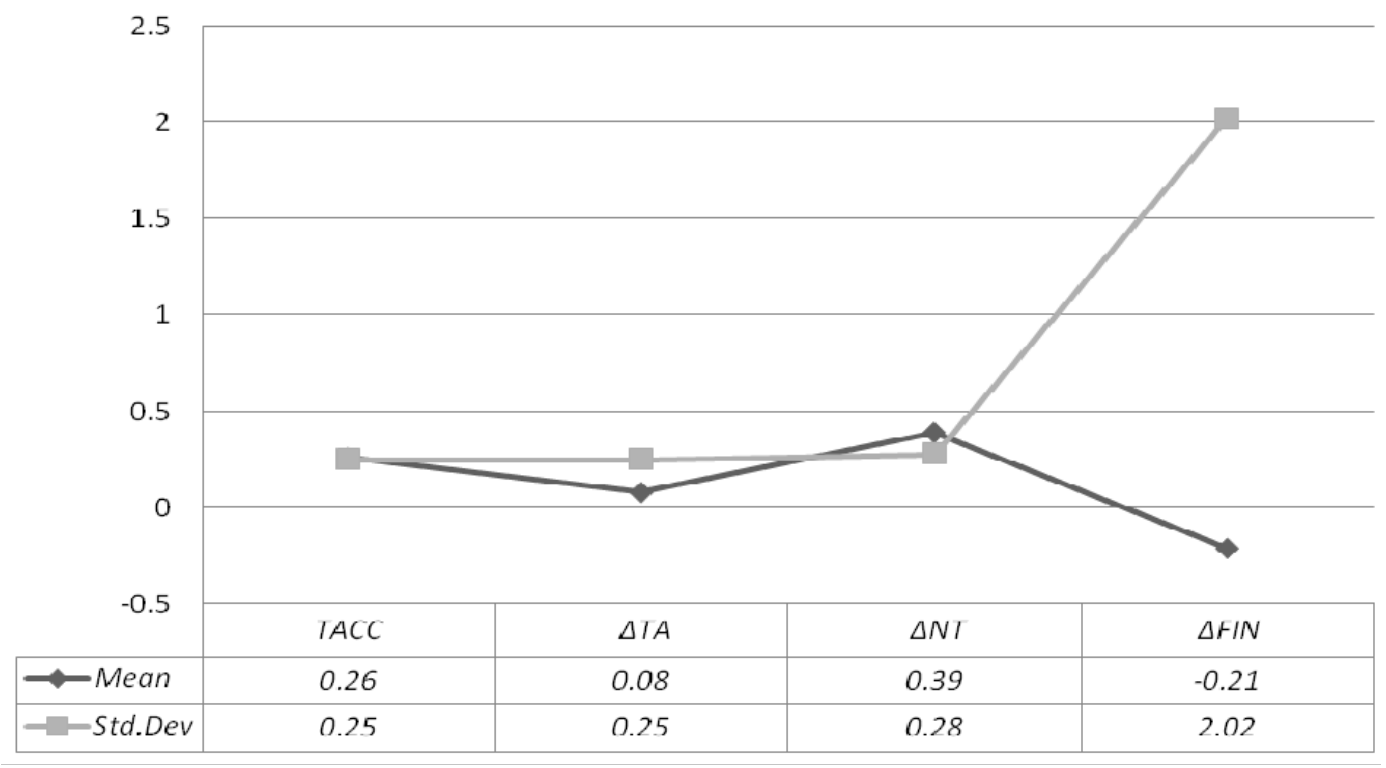

Figure 1. Descriptive statistic for initial accruals

The sample consist of 38,160 firm-years between 1991 and 2008

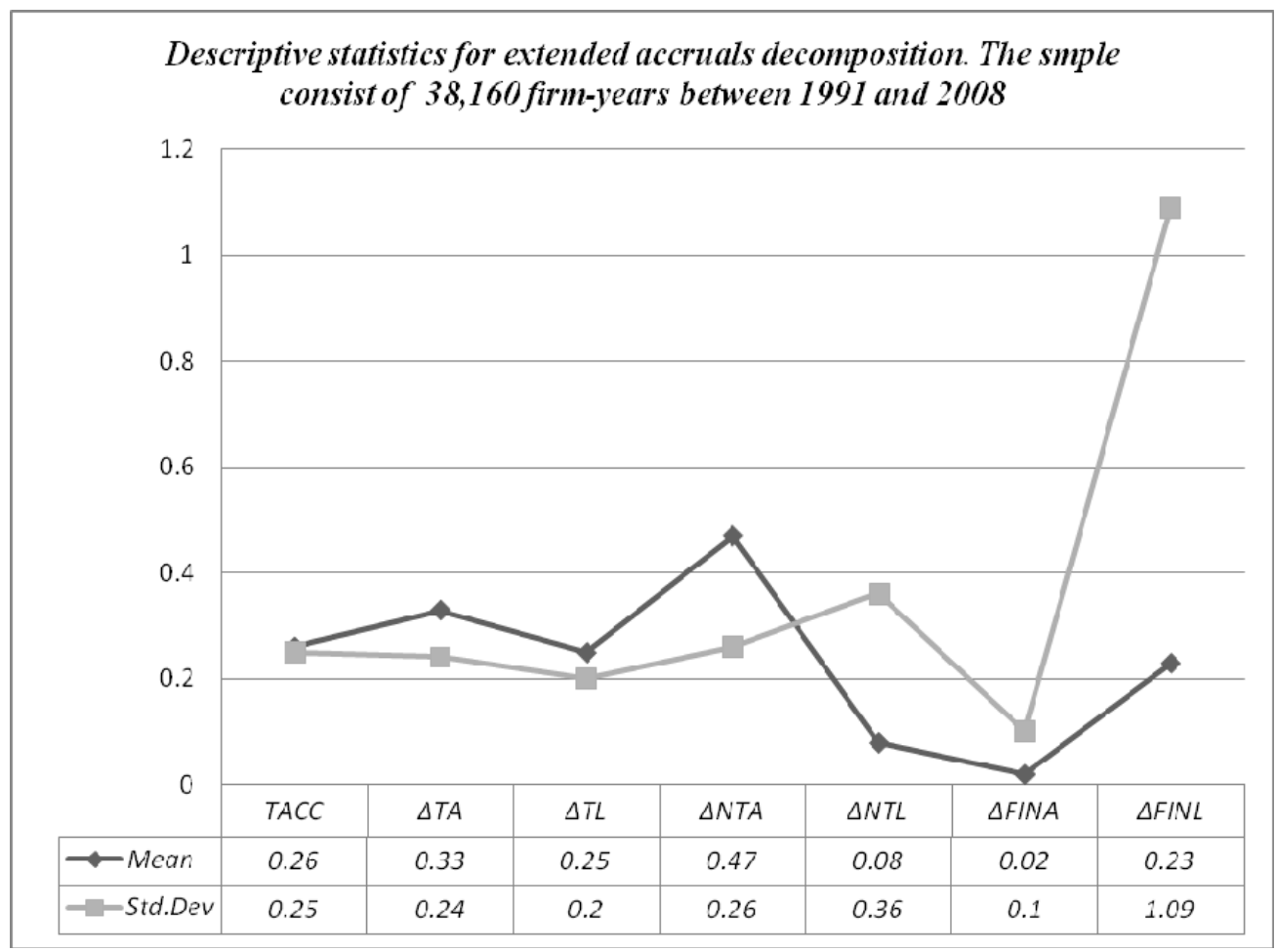

Figure 2. Descriptive statistics for extended accruals decomposition

The sample consist of 38,160 firm-years between 1991 and 2008 